\title{
Dengue Cases Prediction in Kupang
}

\author{
Titik Respati, ${ }^{1}$ Wanti, ${ }^{2}$ Ricvan Dana Nindrea ${ }^{3}$ \\ ${ }^{1}$ Department of Public Health, Faculty of Medicine, Universitas Islam Bandung, Bandung, Indonesia, \\ ${ }^{2}$ Politeknik Kesehatan Kemenkes Kupang, Kupang, Indonesia, ${ }^{3}$ Department of Public Health and \\ Community Medicine, Faculty of Medicine, Universitas Andalas, Padang, Indonesia
}

\begin{abstract}
The pandemic of coronavirus (COVID-19) causes another infectious disease such as dengue is neglected in Indonesia. Since the majority of resources, both human and capital, are focusing more on COVID-19, it is still essential to also manage dengue as it is still becoming a threat to the community. This study aims to predict the number of cases of dengue in Kupang, East Nusa Tenggara, Indonesia. This study area is in Kupang city, East Nusa Tenggara province, Indonesia. Data regarding monthly dengue reported cases by months from January 2010-December 2019 in Kupang city was collected to describe the temporal patterns of dengue cases. The Box-Jenkins approach is used to fit the auto-regressive integrated moving average (ARIMA) models. This model will predict monthly dengue cases for the year 2020 (12 months). Data analyzed using the Minitab program version 18.0. This study shows that seasonality was an essential component for Kupang city, which performed an exploratory analysis of dengue incidence (ln data) for 2010-2019. The linear trend model shows the prediction of dengue cases in 2020 was $Y t=36.9-0.131 \times t$. The forecast tells that dengue will remain high for the whole year. Maintaining a clean environment, reduction of breeding sites, and other protective measurements against dengue transmission are significant to perform.
\end{abstract}

Keywords: COVID-19, dengue, prediction

\section{Prediksi Kasus Demam Berdarah Dengue di Kupang}

\begin{abstract}
Abstrak
Pandemi virus corona (COVID-19) mengakibatkan penyakit menular lain seperti dengue terbengkalai di Indonesia karena mayoritas sumber daya, baik manusia maupun permodalan, lebih berfokus pada COVID-19, sedangkan penanggulangan demam berdarah dengue (DBD) masih menjadi hal yang penting karena masih menjadi ancaman bagi masyarakat. Penelitian ini bertujuan memprediksi jumlah kasus DBD di Kupang, Nusa Tenggara Timur, Indonesia. Wilayah studi ini berada di Kota Kupang, Provinsi Nusa Tenggara Timur, Indonesia. Data bulanan kasus DBD yang dilaporkan per bulan dari Januari 2010-Desember 2019 di Kota Kupang dikumpulkan untuk menggambarkan pola temporal kasus DBD. Pendekatan Box-Jenkins digunakan untuk menyesuaikan model autoregressive integrated moving average (ARIMA). Model ini akan memprediksi kasus DBD bulanan untuk tahun 2020 (12 bulan). Data dianalisis menggunakan program Minitab versi 18.o. Studi ini menunjukkan bahwa musim merupakan komponen penting bagi Kota Kupang yang melakukan analisis eksplorasi kejadian DBD (dalam data) untuk tahun 2010-2019. Model tren linier menunjukkan prediksi kasus DBD tahun 2020 adalah Yt=36.9-0.131 $\times \mathrm{t}$ yang memperkirakan DBD akan tetap tinggi sepanjang tahun. Menjaga kebersihan lingkungan, mengurangi tempat berkembang biak, dan tindakan perlindungan lainnya terhadap penularan DBD penting dilakukan.
\end{abstract}

Kata kunci: COVID-19, DBD, prediksi 


\section{Introduction}

During the coronavirus (COVID-19) pandemic, almost all other diseases suffer from neglect from health officials and the community. In Indonesia, from the first confirmed cases of COVID-19 in early March until April 29, 2020, it already recorded 9,511 cases with 773 fatalities. ${ }^{1}$ Government and hospitals continue to increase the allocation of personnel and medical devices for handling COVID-19, and as a result, the handling of other diseases such as dengue is neglected. ${ }^{2}$ Simultaneously, the Ministry of Health Republic of Indonesia recorded that from January to the first week of July 2020, there were around 72 thousand cases of dengue nationally with 459 fatalities. ${ }^{3}$

East Nusa Tenggara was one of the provinces with the highest number of cases together with East Java. Until March 2020, there were 3,731 dengue cases in all of East Nusa Tenggara, with 43 fatalities. ${ }^{4}$ Dengue is still a significant public health threat that needs attention. ${ }^{5,6}$ Researchers concerned about dengue fever and COVID-19 are difficult to distinguish because they share clinical and laboratory features. Some cases of COVID-19 diagnosed as dengue are already reported in some hospitals. A new strain of this virus will probably contribute to a more complicated human-endemic transmission..$^{7,8}$

Peri-domestic mosquitoes transmit dengue hemorrhagic fever through Aedes aegypti and Aedes albopictus as the vectors. ${ }^{9}$ Especially in developing countries, the development-related activities, particularly concerning water storage, increase the mosquito habitats and the risk of disease..$^{10-13}$ Identifying the cause of a disease is a significant factor in its control. There are multifactor effects that are highly dynamic and change over time. ${ }^{8,14-16}$ In several studies, the failure to achieve an intervention program objective is usually due to the program not being designed comprehensively and not taking a whole system perspective. ${ }^{17-19}$ Studies found that the dengue prevention and control program was the most decisive disease prevention factor..$^{19,20}$ The program to eradicate dengue in Indonesia started at the beginning of the first cases. However, all efforts to suppress the spread of dengue for decades are now threatened by COVID-19.

East Nusa Tenggara Government already conducted some programs to control dengue following the Ministry of Health guidance. ${ }^{21}$
Some activities were fogging to control the Aedes aegypti mosquito, distributing anti-mosquito lotions for free, and distributing abate powder to cut off the regeneration of infectious mosquitoes. However, studies stated that fogging is not sufficient to eradicate mosquitos. ${ }^{8,22,23}$ The local government has also distributed anti-mosquito drugs to schools. Some regions open 24-hour posts for dengue infection detection services with rapid test kits such as the ELISA test. The government's challenge is that as the management of COVID-19 resorbs many sources, both human and capital, it is still important to manage dengue as it is still becoming a threat to the community. It is essential, especially for the government and community, to stay alert to dengue. This paper aims to predict the number of dengue cases in Kupang, East Nusa Tenggara, which can help the government plan for dengue program activities.

\section{Methods}

This observational study conducted in the study area in Kupang city, the capital city of East Nusa Tenggara province, Indonesia, located at $10^{\circ} 36^{\prime} 14^{\prime \prime}-10^{\circ} 39^{\prime} 58^{\prime \prime S}$ and $123^{\circ} 32^{\prime} 23^{\prime \prime}-$ $123^{\circ} 37^{\prime} 01^{\prime \prime E}$. It covers an area of $180.27 \mathrm{~km}^{2}$. The average temperature in Kupang city ranges from $23.8^{\circ} \mathrm{C}$ to $31.6^{\circ} \mathrm{C}$. The average air humidity ranges from $73 \%$ to $99 \%$. Rainfall was $1,720.4 \mathrm{~mm}$, and rainy days were 152 days. The highest rainfall occurred in January with $598.3 \mathrm{~mm}$, while the highest rainy day occurred in December with 28 rainy days. Geographic and weather condition makes Kupang city ideal for dengue. ${ }^{17}$

Data regarding monthly dengue reported cases by months from January 2010-December 2019 in Kupang city, East Nusa Tenggara province, Indonesia, were collected from various relevant governmental departments. Data analysis is used for describing the temporal patterns of dengue cases in Kupang city by plotting monthly and yearly incidence for the study period. Data presented in table and graphic. This data analysis evaluated the data's overall features using the graphical approach: trends (increase, decrease), seasonality, and outliers. We estimate the parameter using the Box-Jenkins approach to fit the auto-regressive integrated moving average (ARIMA) models. This model will predict monthly dengue cases for the year 2020 (12 months). Data analyzed using the Minitab program version 18.0. 


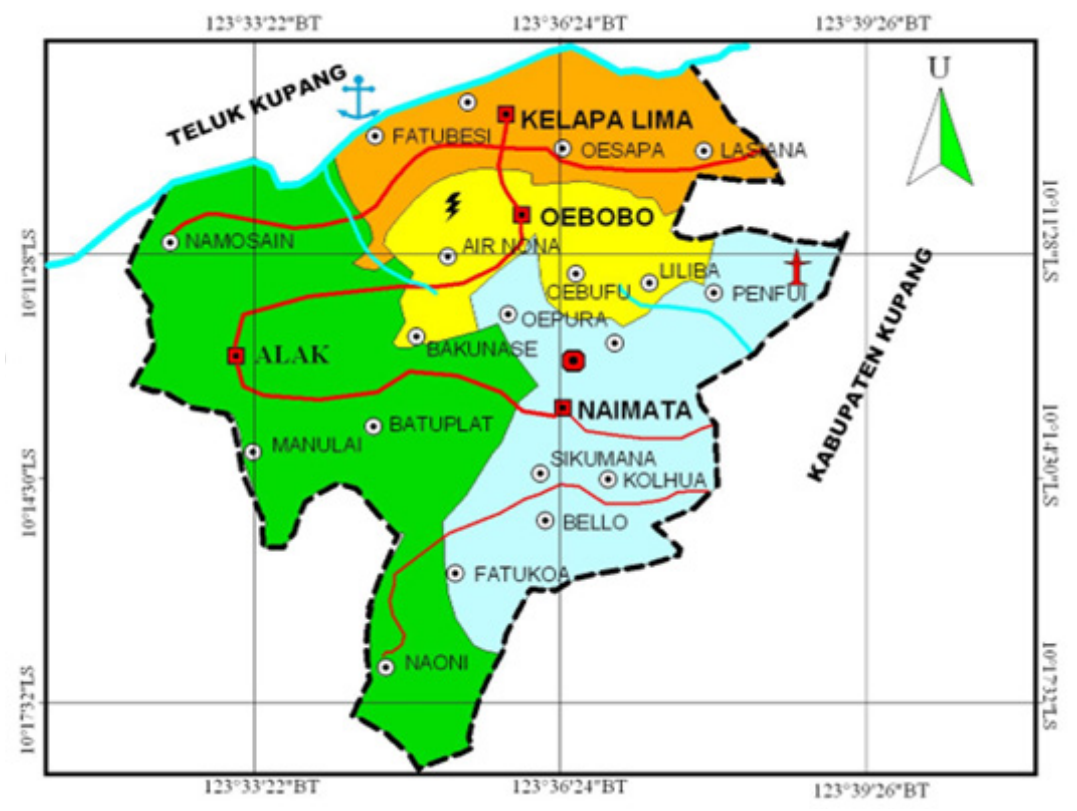

Figure 1 Map of Kupang City

\section{Results}

Figure 2 found in the Kupang city, the yearly incidence of dengue varied from 351 cases in 2010 to 609 cases in 2019, during the study period (2010-2019). The higher incidences were registered in the years: $2012(\mathrm{n}=890)$ and 2019 $(\mathrm{n}=609)$.

Figure 3 showed that seasonality was an essential component for the Kupang city, which performed an exploratory analysis of dengue incidence (ln data) for 2010-2019. The analysis showed that the highest incidence was registered from December to February with four outliers of 308 and 352 dengue cases registered in January and February 2012, 161 and 119 dengue cases in March 2012, and 2016 lowest incidence from May to November.

Figure 4 showed a linear trend model to predict dengue cases in 2020 was $\mathrm{Yt}=36.9-0.131$

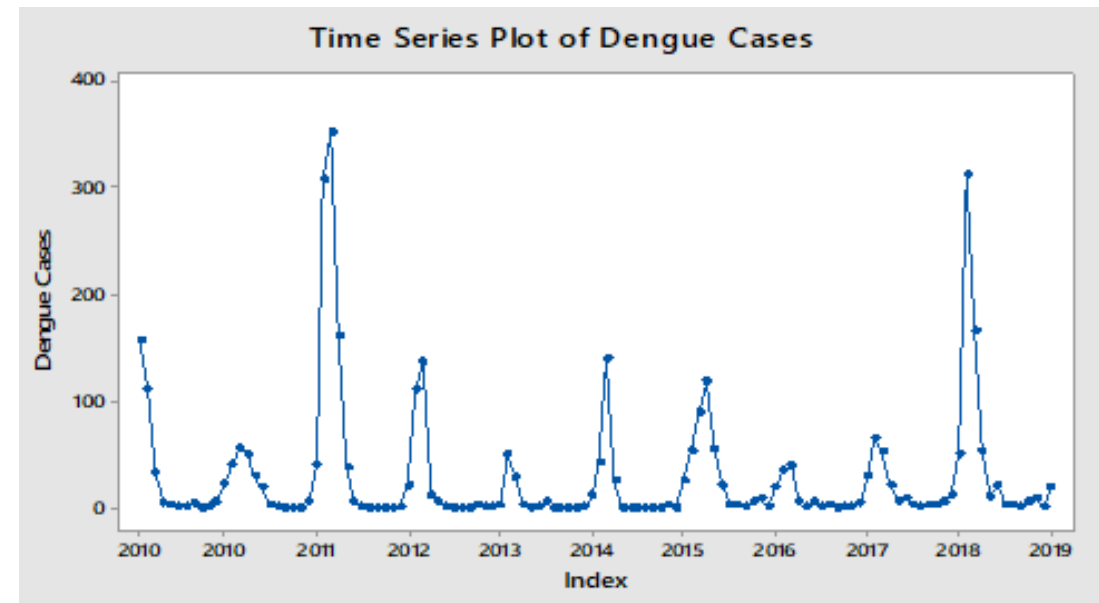

Figure 2 Reported Monthly Dengue Case Data in Kupang City, East Nusa Tenggara Province, Indonesia (2010-2019) 


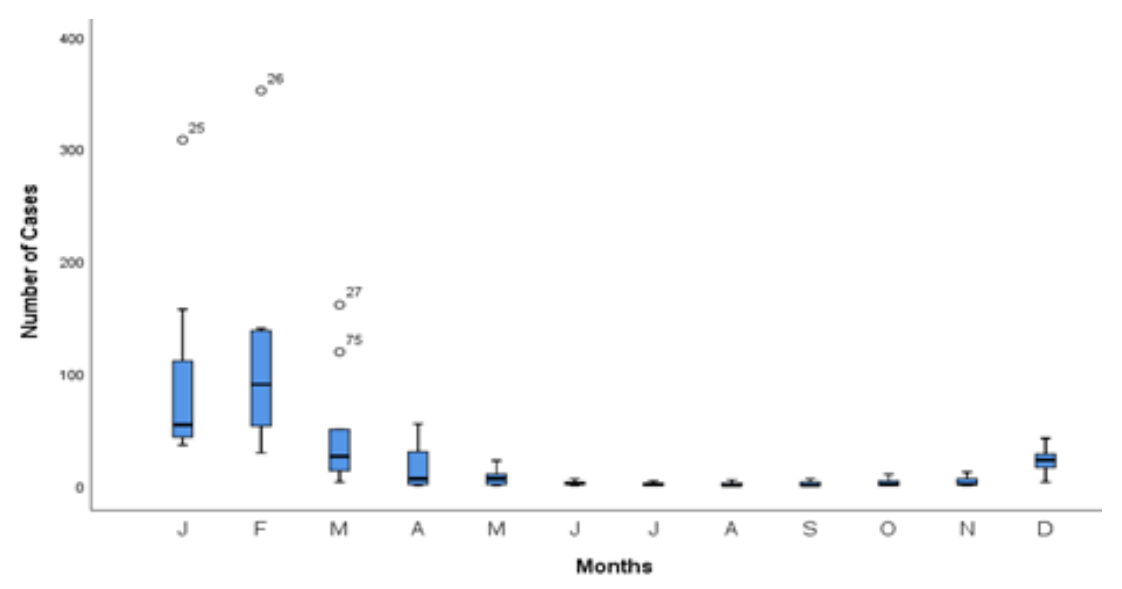

\section{Figure 3 Seasonal Box-plot Distribution of Monthly Dengue Cases in Kupang} City, East Nusa Tenggara Province, Indonesia (2010-2019)

$x \mathrm{t}$. Table shows the monthly forecast of dengue cases according to the model in 2020 for Kupang city. The model predicted the total number of dengue cases for 2020 was 263 varying from 23 dengue cases in January and February, 22 dengue cases in March to September, and 21 cases dengue cases in October to December.

\section{Discussion}

Dengue, caused by infection with any of the four dengue virus serotypes (DENV-1, DENV2, DENV-3, and DENV-4), is one of the most important mosquito-borne viral diseases as a major public health concern. Since its first report in 1968, Indonesia is still vulnerable to the dengue outbreak. In Indonesia, the outbreak pattern is roughly recorded every 6-8 years, since 1973, 1988, 1998, 2009, 2016, and now in 2019.5,17 The country's vulnerability to dengue outbreak due to many factors such as sifting of dengue serotype, environment condition and people behavior, programmatic factors for prevention, control, and case management and government commitment. ${ }^{12}$

One study of the dengue outbreak in 1998 reveals that DENV-3, which is generally associated with the dengue outbreak in Indonesia, had a newly isolated genotype within DENV-3 that was never reported in Indonesia before 1998. This new isolated DENV-3 genotype is commonly circulated in Thailand. The finding indicated

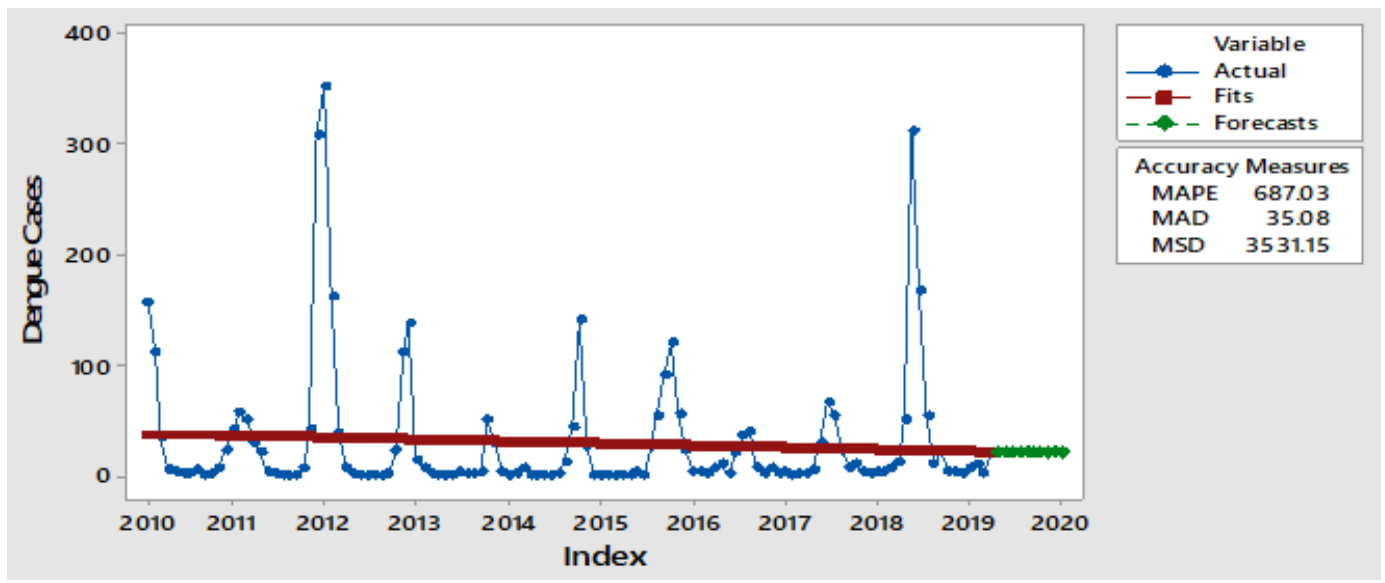

Figure 4 Trend Analysis Plot for Dengue Cases Based on Linear Trend Model Note: $\mathrm{Yt}=36.9-0.131 \times \mathrm{t}$ 
Table Forecasted Monthly Dengue Cases for Kupang City, East Nusa Tenggara, Indonesia in 2020

\begin{tabular}{ccc}
\hline Period & $\begin{array}{c}\text { Months } \\
\text { (2o20) }\end{array}$ & $\begin{array}{c}\text { Predicted } \\
\text { Cases }\end{array}$ \\
\hline 109 & January & 23 \\
110 & February & 23 \\
111 & March & 22 \\
112 & April & 22 \\
113 & May & 22 \\
114 & June & 22 \\
115 & July & 22 \\
116 & August & 22 \\
117 & September & 22 \\
118 & October & 21 \\
119 & November & 21 \\
120 & December & 21 \\
\multicolumn{3}{c}{ Total } \\
\hline
\end{tabular}

that these new viruses have been imported into Indonesia and established its local transmission and associated with the increases of DHF cases. ${ }^{17}$

East Nusa Tenggara is the area with a dry spell in some months of the year, usually from June to September and heavy rains in the other months of December to March. People prepared for water scarcity during dry seasons by storing water in the containers, which usually are not properly closed. As dengue viruses are transmitted through the bite of infected Aedes aegypti and Aedes albopictus female mosquitoes, the available water for breeding places is essential for an outbreak. Our recent observation in West Java and Timor shows that some standing water, including puddles, water tanks, containers, and old tires, are still the main Aedes breeding sites. ${ }^{5,14,18} \mathrm{~A}$ lack of community participation and government commitment to provide better and reliable sanitation and regular garbage collection also contribute to the spread of the mosquitoes. ${ }^{15,17}$

Our data shows that dengue incidences were peak in the rainy season, from December to April. The rainy season was more comfortable for the mosquito to breed in lots of newly created standing water. During this period, the number of possible new cases depends on how regions prevent the spread of the disease by controlling their surrounding environment, better sanitation measures, regular garbage collection, and the prevention of newly created standing water for mosquitoes to breed. The government developed several dengue prevention programs, such as larvae monitoring interpreter (juru pemantau jentik, Jumantik) and clean Friday (Jumat bersih, Jumsih), to suppress dengue incidence. Jumantik, whose task is to monitor mosquitoes' larvae and pupae's presence, is created to ensure that the community's water containers are free from larvae and pupae. Jumsih is the activity every Friday when all community members clean their environment together.

Although Indonesia Government has made efforts, both the incidence and case-fatality rates are still high during the dengue outbreak and not showing significant changes. In our observation from the programmatic review, a dengue surveillance system cannot provide a timely alert for anticipating the outbreak. Many outbreak events were realized by the authority when lots of cases and deaths were published on the news. 799 Community knowledge, awareness, and involvement against dengue play crucial roles in preventing dengue outbreaks. ${ }^{15}$ During the recent dengue outbreak, government attention to anticipate the COVID-19 pandemic put the cost on more dengue cases and deaths in East Nusa Tenggara. This condition worsens by the unavailability of adequate laboratory capacity to detect and dengue diagnose. ${ }^{19}$

Central Government must send specialist and laboratory equipment to support East Nusa Tenggara during the dengue outbreak.$^{17}$ A similar condition is also reflected by the East Nusa Tenggara Government's limited capacity to perform adequate and timely COVID-19 sample testing. All samples of COVIDd-19 must send to referral laboratories for COVID-19, and it takes 7-14 days for the results to come. Not to mention the difficulties of sending the sample out from East Nusa Tenggara to Jakarta due to travel retractation during the regional lockdown and domestic travel ban [4,18].4,18 The preliminary unreviewed version of this articles is published in preprints.org. ${ }^{24}$

\section{Conclusions}

As dengue claimed more life than COVID-19 in East Nusa Tenggara, the local government is more concerned about overcoming this outbreak. However, the global domino effects of the COVID-19 pandemic have put more burden on local government-which has limited resources to focus on both dengue and COVID-19 at the 
same time. Community and government have to be informed that the stay at the home approach to preventing COVID-19 increases the chances of getting dengue virus if there is not enough effort to maintain a clean environment, reduce breeding sites, and other protective measures against dengue transmission.

\section{Conflict of Interest}

There is no conflict of interest at all authors.

\section{Acknowledgments}

The authors would like to thank the Health Office of Kupang city and the Health Office of East Nusa Tenggara.

\section{References}

1. Direktorat Pencegahan dan Pengendalian Penyakit Kementerian Kesehatan Republik Indonesia. Pedoman pencegahan dan pengendalian coronavirus disease (COVID-19). $4^{\text {th }}$ revision [Internet]. Jakarta: Kementerian Kesehatan Republik Indonesia; 2020 March 27 [cited 2020 July 15]. Available from: https://infeksiemerging.kemkes. go.id/download/REV-04_Pedoman_P2_ COVID-19_27_Maret2020_TTD1.pdf.

2. Sutrisno E. Tak kesampingkan dengue karena corona [Internet]. Jakarta: Indonesia go id; 2020 March 22 [cited 2020 June 16]. Available from: https://indonesia.go.id/ kategori/indonesia-dalam-angka/1731/takkesampingkan-dengue-karena-corona.

3. Kementerian Kesehatan Republik Indonesia. Hingga Juli, kasus DBD di Indonesia capai 71 ribu [Internet]. Jakarta: Kementerian Kesehatan Republik Indonesia; 2020 July 9 [cited 2020 July 26]. Available from: https://www.kemkes.go.id/article/ view/20070900004/hingga-juli-kasus-dbddi-indonesia-capai-71-ribu.html.

4. Septianto B. Angka kematian akibat DBD di NTT mencapai 43 orang [Internet]. Jakarta: Tirto id; 2020 March 18 [cited 2020 July 28]. Available from: https://tirto.id/angkakematian-akibat-dbd-di-ntt-mencapai-43orang-eFZu.

5. Edillo F, Madarieta S. Trends of dengue infections (1997-2008) in Cebu province, Philippines. Dengue Bull. 2012;36:37-49.

6. de Jong W, Rusli M, Bhoelan S, Rohde S,
Rantam FA, Noeryoto PA, et al. Endemic and emerging acute virus infections in Indonesia: an overview of the past decade and implications for the future. Crit Rev Microbiol. 2018;44(4):487-503.

7. Chen N, Zhou M, Dong X, Qu J, Gong F, Han Y, et al. Epidemiological and clinical characteristics of 99 cases of 2019 novel coronavirus pneumonia in Wuhan, China: a descriptive study. Lancet. 2020;395(10223):507-13.

8. Arunachalam N, Tyagi BK, Samuel M, Krishnamoorthi R, Manavalan R, Tewari SC, et al. Community-based control of Aedes aegypti by adoption of eco-health methods in Chennai City, India. Pathog Glob Health. 2012;106(8):488-96.

9. Wanti, Yudhastuti R, Notobroto HB, Subekti S, Ekawati C, Agustina. Container characteristics and dengue hemorrhagic fever incidence. Int $\mathrm{J}$ Public Health Sci. 2019;8(3):314-9.

10. Wanti, Yudhastuti R, Notobroto HB, Subekti S, Sila O, Kristina RH, et al. Dengue hemorrhagic fever and house conditions in Kupang city, East Nusa Tenggara province. Kesmas. 2019;13(4):176-81.

11. Respati T, Feriandi Y. Breeding places of mosquito larvae and pupae in Bandung city. J Phys Conf Ser. 2020;1469:012119.

12. Wai KT, Arunachalam N, Tana S, Espino F, Kittayapong P, Abeyewickreme W, et al. Estimating dengue vector abundance in the wet and dry season: implications for targeted vector control in urban and peri-urban Asia. Pathog Glob Health. 2012;106(8):436-45.

13. Respati T, Raksanagara A. Larvae and pupae in Bandung city: can they be the indicators of dengue outbreak? In: Abdullah AG, Widiaty I, Abdullah CU, editors. Medical Technology and Environmental Health: Proceedings of the Medicine and Global Health Research Symposium (MoRes 2019); 2019 October 22-23; Bandung, Indonesia. Leiden: CRC Press/Balkema; 2020. p. 332-7.

14. Respati T, Raksanagara A, Wangsaputra R. Basic sanitation: is it an important factor in dengue transmission? In: Abdullah AG, Widiaty I, Abdullah CU, editors. Medical Technology and Environmental Health: Proceedings of the Medicine and Global Health Research Symposium (MoRes 2019); 2019 October 22-23; Bandung, Indonesia. Leiden: CRC Press/Balkema; 2020. p. 270-3. 
15. Luz PM, Vanni T, Medlock J, Paltiel AD, Galvani AP. Dengue vector control strategies in an urban setting: an economic modelling assessment. Lancet. 2011;377(9778):167380.

16. Stahl HC, Butenschoen VM, Tran HT, Gozzer E, Skewes R, Mahendradhata Y, et al. Cost of dengue outbreaks: literature review and country case studies. BMC Public Health. 2013;13:1048.

17. Respati T, Feriandi Y, Ndoen E, Raksanegara A, Djuhaeni H, Sofyan A, et al. A qualitative ecohealth model of dengue fever (DF) in Bandung, Indonesia. Int $\mathrm{J}$ Trop Dis. 2018;1(1):008.

18. Toledo ME, Baly A, Vanlerberghe V, Rodríguez M, Benitez JR, Duvergel J, et al. The unbearable lightness of technocratic efforts at dengue control. Trop Med Int Heal. 2008;13(5):728-36.

19. Eisen L, Coleman M, Lozano-Fuentes S, McEachen N, Orlans M, Coleman M. Multidisease data management system platform for vector-borne diseases. PLoS Negl Trop Dis. 2011;5(3):e1016.

20. Zeng W, Halasa-Rappel YA, Baurin N, Coudeville L, Shepard DS. Cost-effectiveness of dengue vaccination in ten endemic countries. Vaccine. 2018;36(3):413-20.

21. Direktorat Jenderal Pengendalian Penyakit dan Penyehatan Lingkungan, Kementerian
Kesehatan Republik Indonesia. Pedoman pencegahan dan pengendalian demam berdarah dengue di Indonesia [Internet]. Jakarta: Direktorat Jenderal Pengendalian Penyakit dan Penyehatan Lingkungan, Kementerian Kesehatan Republik Indonesia; 2017 [cited 2020 June 28]. Available from: http://kesmas-id.com/download/ pedoman-pencegahan-pengendalian-dbddi-indonesia-2017/?wpdmdl=23036\&refres $\mathrm{h}=6137147675$ aad1630999670.

22. Balasubramanian R, Anukumar B, Nikhil TL. Stegomyia indices of Aedes mosquito infestation and container productivity in Alappuzha district Kerala. Int J Mosq Res. 2015;2(2):14-8.

23. Tana S, Abeyewickreme W, Arunachalam N, Espino F, Kittayapong P, Wai K, et al. Eco-bio-social research on dengue in Asia: general principles and a case study from Indonesia. In: Charron DF, editor. Ecohealth research in practice: innovative applications of an ecosystem approach to health. Ottawa: International Development Research Centre; 2012. p. 173-84.

24. Respati T, Wanti W, Nindrea RD. Prediction of dengue cases in Kupang, East Nusa Tenggara, Indonesia. Preprints (Basel) [Internet]. 2020 April 30 [cited 2020 July 30];2020:0539. Available from: https://doi. org/10.20944/preprints202004.0539.v1. 